\title{
İlkokul Öğrencilerinin Müzik Türü Tercihleri Üzerine Bir İnceleme
}

\author{
Dr. Halil Taş \\ Milli Ĕ̆gitim Bakanlı̆̆ı, Teftiş Kurulu \\ egitimci1@hotmail.com
}

Öz

$\mathrm{Bu}$ çalışma, ilkokul 4. sınıf öğrencilerinin, müzik türü tercihlerini, bu tercihlerinin nedenlerini, velilerin ve öğretmenlerin öğrencilerin müzik türü tercihlerine ilişkin görüşlerini eğitimsel ve sosyolojik açıdan ortaya koymayı amaçlamaktadır. Popüler kültürün ve popüler müzik türlerinin yükselişinin neden ve sonuçları da bu çalışmada değinilen konular arasındadır. $\mathrm{Bu}$ çalışmada nitel araştırma desenlerinden fenomenolojik (olgubilim) desen kullanılmıştır. 3 okulda gerçekleştirilen araştırmanın çalışma grubunu amaçlı örnekleme yöntemlerinden ölçüt örnekleme yöntemiyle belirlenen 27 öğrenci, 27 veli ve 12 sinıf öğretmeni oluşturmaktadır. Araştırmada veri toplama aracı olarak yarı yapılandırılmış anket ve görüşme formu kullanılmıştır. Elde edilen veriler, betimsel analiz yöntemiyle çözümlenmiştir. Araştırmada Hiphop-Rap müzik türünün en çok tercih edilen müzik türü olduğu, en az tercih edilen müzik türünün ise Klasik Müzik olduğu, okul şarkılarının öğrenciler tarafından fazla tercih edilmeyen bir müzik türü olduğu, öğrencilerin müzik türü tercihlerinde müzik türünün yaygın dinlenmesinin, sanatçısının ve klibinin etkili olduğu; öğrencilerin kendi dinledikleri müzik türlerini faydalı gördükleri, öğretmenlerin ve velilerin ise öğrencilerin en çok tercih ettikleri popüler müzik türlerini faydasız ve kötü olarak algıladıkları belirlenmiştir.

Anahtar Kelimeler: Müzik, müzik türleri, müzik eğitimi, popüler müzik, popüler kültür.

\section{An Investigation on the Music Genre Preferences of Primary School Students}

\begin{abstract}
This study aims to reveal primary school 4th grade students' music genre preferences, the reasons of these preferences, and the opinions of parents and teachers about students' preferred music genres. The reasons and results of the rise of popular culture and popular music genres are among the topics mentioned in this study. In this study, phenomenological pattern, one of the qualitative research patterns, was used. The research has been carried out in 3 schools. The study group of the research consists of 27 students, 27 parents and 12 primary school teachers. The study group of the research was determined by criterion sampling method, which is one of the purposeful sampling methods. In the research, semi-structured questionnaire and interview form were used as the data collection tool. The data obtained were analyzed by descriptive analysis method. In the research, it was determined that Hiphop-Rap music type is the most preferred music type and the least preferred music type is Classical Music. It was also revealed that school songs are a type of music that is not preferred by students. It was found that the common listening of the music genre, the artist and the clip were effective in the music genre preferences of the students. In addition, it was determined in the research that students consider the types of music they listen to as useful, while teachers and parents perceive the popular music types that students prefer most as useless and bad.
\end{abstract}

Keywords: Music, music genres, music education, popular music, popular culture. 


\section{GİRIŞ}

Popüler kültür, genel olarak hızlı üretilen ve hızlı tüketilen, tarihsel önemi, derinliği veya devamlılığı bulunmayan, seçkin nitelik taşımayan, ortalama insanların sahip olduğu kültürel özellikler olarak tanımlanmaktadır (Demir, 2020). Bu kavram, modern toplumlarda yaygın halk kültürü veya egemen kitlenin kültürü, çokça tüketilen, toplumda yaygın olarak bulunan ve gündelik olarak yaşanan kültürü ifade etmek için kullanılmaktadır (Kaya, Baysal \& Kurt, 2007, s. 36). Alt toplumsal tabakaların kültürü olan popüler kültür; hâkim tabakaların, hâkimiyetlerini devam ettirebilmeleri için dünya görüşlerini yeniden üreterek arz ettikleri, zevklerin, isyanların, saldırıların, direnişlerin, öykünmelerin, bağımlılıkların kültürüdür (Özkan, 2006, s. 34). Gündelik yaşam kültürü olan popüler kültür, bir taraftan emeğin gündelik olarak yeniden üretilmesinin bir girdisi olarak eğlenceyi kapsarken; diğer taraftan belirli bir yaşam tarzının ideolojik olarak yeniden üretilmesinin ön koşullarını sağlar (Oktay, 2002).

Yerine göre demokratikleşmeyi, yerine göre kişisel zevkleri kullanan popüler kültür, "1smarlama" kitle kültürünün/endüstri kültürünün en çok kullanılan ürünlerinin üretilmesini ve tüketilmesini özendiren düşünceleri ve duyarlılıkları anlatır (Erdoğan \& Alemdar, 2005, s. 70). Kitle kültürü ve kültür endüstrisi kavramları eleştirel teorinin kapsadığ1 düşünce alanına ait kavramlardır (Akkol, 2019, s. 54). Kitle kültürü veya kültür endüstrisi; seri üretim merkezli, adaletten yoksun, baskı ve sömürü içeren bir düzeni ifade eder. Büyük çıkar çevrelerinin, kendi çıkarları doğrultusunda insanlara dayattığı bir düzeni tanımlayan kültür endüstrisinde müzik, bu kültürün/düzenin hedefinde olan bir öge haline gelmiş, büyük çıkar çevrelerince kullanılan ve yönetilen bir kültür ögesi ve sanat dalı olmuştur. Kültür endüstrisinde müziğin, kitleleri sorgulamaktan uzaklaştırmak ve mevcut sisteme kolayca uyumlarını sağlamak amacıyla kullanıldığını söyleyebiliriz (Akkol, 2018, s.118-19). Popüler kültürün kitle iletişim araçlarına veya onları kontrol etme gücüne sahip olan bir azınlık ya da egemen sınıflar tarafından yönlendirildiği ifade edilebilir (Algül, 2019, s. 148).

Popüler kültür kavramının ortaya çıkması ile kültürel ve maddesel üretim alanlarına da bu adlandırma yansımış, popüler müzik de popüler kültürün bir ürünü olarak ortaya çıkmıştır (Gidiş, 2018, s. 2). Popüler kültürle eş zamanlı olarak gelişen popüler müzik türlerinin tercih edilme oranlarının, sadece ülkemizde değil, diğer batı ülkelerinde de diğer müzik türlerini geçtiği bilinmektedir (Aksu, 2008, s. 17). Popüler müzik; ritmik yapısı ve hafızada kolayca kalabilen melodileri ve çok çeşitli akustik ve elektronik çalgıların kullanılması sayesinde gençleri peşinden koşturan ve çoğunlukla dans etmek veya eğlenmek amacıyla yapılan bir müzik türü olarak tanımlanabilir (Çiftçi, 2010, s. 152). Popüler müzik türleri, sanayileşme ve makineleşmenin sistemin dışına ittiği işsizlerin sahip oldukları boş zaman olgusuna büyük ölçüde eşlik etmektedir. Gençlerimiz için bu müzik türleri, duyguların belli biçimlerde ifade edilmesini ve belli bir gruba ait olmayı sembolize ederken; çocuklarımız için şarkı söyledikleri, dans edip oyun oynadıkları eğlenceli bir etkinliği ifade etmektedir (Aksu, 2008, s. 22).

Günümüzde müzik, her kesimden insanın yaşamında önemli yer tutan, insanların birçok alanda yararlandığı, bazen de insanların sorunlarının çözmek için başvurdukları etkili bir araç haline gelmiştir. Birbirinden farklı türleri bulunan müzik, toplum yaşamının birçok alanında bazen öncü, bazen destekleyici, bazen de belirleyici roller üstlenmektedir (Çiftçi, 2010, s. 150). Müzik, çağımızda ruhsal hastalıkların tedavisinden, işyerlerinde 
üretimin artırılmasına, öğrenmenin hızlandırılmasından, topraktan ve hayvanlardan daha fazla verim alınmasına kadar birçok alanda kullanılmaktadır (Yağışan, 2013, s. 98). Müzik insan yaşamında çok etkili olan duyguların ve olayların yorumlamasında ve dillendirilmesinde önemli roller üstlendiği (Sakar \& Maba, 2015), zengin yapısı ve tür çeşitliliğiyle toplumların ve bireylerin kültürel yapıları üzerinde önemli etkileri olduğu söylenebilir.

Müziğin ev, sokak, okul, çalışma hayatı, oyun, eğlence ve dinlence ortamları, görsel ve işitsel medya, sinema, konser, tören ve toplantı gibi hayatın her alanında ve her evresinde insanı kuşatan, neredeyse insan yaşamının odağında yer alan bir olgu olduğu söylenebilir (Uçan, 2018). Dolayısıyla, bebeklikten başlayarak insan yaşamının son anına kadar süren müzikle iletişim ve etkileşimin, insan yaşamının vazgeçilmez unsurlarından biri olduğu söylenebilir. Müziğin gelişme ve değişmelerden etkilenme özelliği ile gelişme ve değişmeleri başlatma özelliğinin varlı̆̆ı, kendisini daha da önemli hale getirmektedir. Müziğin sadece bireylerin müziksel gelişimleri ile sinırlı olmayan; bireylerin akademik, fiziksel, toplumsal ve kültürel gelişimleri üzerinde de yadsınamaz bir etkileme gücü bulunmaktadır (Kılıç, 2016, s. 360).

Günümüz Türkiye'sinde dönüşüm olarak nitelendirilen ekonomik, sosyal ve kültürel değişimin 19. yüzyılın sonlarında başladığı söylenebilir (Kongar, 2014). Uzun süren tek parti yönetiminin ardından, çok partili sisteme geçiş ve 1950 yllında iktidar değişikliği müzik alanında da değişime sebep olmuştur. Yeni iktidar, milli müzik oluşturma gayretlerini terk etmiş ve böylece Batı'dan yeni müzik türleri hızla yurda girmiştir. Bu dönemde yabancı müzikler orijinal halleriyle alınıp orijinal dillerinde söylenmiştir. 1960 yılından sonra yeni anayasanın özgürlükçü yapısı, yabancı fikirler gibi yabancı müziklerin de ülkeye girişini hızlandırmıştır. Yerli orkestraları koruyucu kanunlar yapılmış, yabancı şarkılara Türkçe sözler yazılarak yeni bir tür (aranjman) oluşturulmuş, yabancı müzik formları ile Halk Müziği şarkıları yeniden düzenlenmiş, aynı esaslarla yerli besteler yapılmıştır. Tüm dünyada yaygınlaşan gençlik ve kitle hareketleriyle birlikte ideolojik anlamda müzik sloganlaşmaya başlamıştır. Ülkenin sosyal, ekonomik ve politik değişiminin de etkisiyle değişik yerel müzik türleri de ortaya çıkmıştır. Bunların en etkili olanlarından biri de arabesk müzik türüdür (Ok, 2004; Öztürk, 2002). 1960'l1 yılların ikinci yarısından sonra başlayan ezikliğin, umutsuzluğun, yoksulluğun ve ezilmişliğin sesi "arabesk", 90'l1 yıllara gelindiğinde artık hayatın her noktasında bir yaşam kültürü haline gelmiştir (Özbek, 2013). 1970'li yıllara gelindiğinde, Pop Müzik için atılan tohumlar meyve vermeye başlamıştır. 1980'li yıllarda Türk Pop Müziği, o zamana kadar Türk toplumunda bir hayat tarzı haline gelen arabeski sollamış ve arabeske göre daha şehirli bir görüntü vermesi sebebiyle de oldukça yaygınlaşmıştır. 1990'lardan sonra küreselleşme sürecine giren dünyada, müzik de bundan nasibini almış ve dünya müzikleri arasındaki alışverişler had safhaya ulaşmıştır. $\mathrm{Bu}$ değişim, özellikle az gelişmiş veya gelişmekte olan toplumların müziklerinin, gelişmiş ülkelerin müziklerine benzemenin ötesinde, onların anlayışlarının mutlak hâkimiyeti altına girmelerine neden olmuştur. 2000'li yıllar ise her alanda olduğu gibi müzik alanında da sınırların zorlandığı ve ortadan kalktığı yıllardır (Çetinkaya, 1999). Günümüzde arabeskin gücü kırılmış, iletişim teknolojideki gelişmelere paralel olarak bütün dünyada olduğu gibi ülkemizde de Pop ve Hiphop-Rap müzik gençlerin vazgeçilmezleri arasına girmiştir.

Türkiye'de gerçekleşen sosyal ve kültürel değişimin, ülkenin sanat anlayışını ve buna bağlı olarak müzik kültürünü de yakından etkilediği bir gerçektir (Şahin \& Duman, 2008, s. 
269). Cumhuriyet döneminde Türkiye'de toplumsal ve kültürel alanda yaşanan değişimlerin en önemlilerinden biri de müzik alanında yaşanmıştır. Çünkü müzik, sosyal yapılara dayalı bir sosyal davranışın sonucunda yaratılan ve belli bir kültür içinde yer alan sosyal bir olaydır (Kaplan, 2005). Toplumda meydana gelen kültürel ve sanatsal değişimin bir sonucu olarak müzik anlayışında da değişim yaşanmasının bir sonucu olarak müziği üreten, müziği seslendiren ve müziği dinleyenler arasındaki ilişkiler de değişmiştir. Bu değişim, bireylerin müzik alışkanlıklarını ve tercihlerini çok yönlü olarak etkilemiştir. Özellikle müziğin bir ticari unsur haline dönüşmüş olması gerçeği, müzik piyasasının bireylerin müzik zevklerini, müziğe ilişkin alışkanlıklarını ve eğilimlerini hedef alamsına neden olmuştur. Ticari kaygının başat olduğu bu durum, bireylerin farklı müzik türlerine yönelimlerini artırırken, oluşan popüler kültür, popüler müzik tercihinin ön plana çıkmasına neden olmuştur. Bireylerin kendi beğenilerini oluşturan ve duygularına hitap eden müzikleri çevrelerinde bulunan müzik türleri arasından seçiyor olmaları, popüler kültür tarafından kendilerine sunulan alternatifler arasından seçim yapmalarını salıkvermiştir.

Günümüzün müzik piyasası ticari kaygıları öncelemekle birlikte, bireylerin müzik zevklerini de ciddi boyutta etkileyebilmektedir. Bireyler kendi beğenilerini oluşturan ve duygularını dile getiren müzik türlerini çevrelerindeki müzik türleri arasından seçebilmektedir. Bir müziği sevip sevmemek bireysel zevk veya tercih olarak değerlendirilebileceği gibi, toplumsal statü göstergesi olarak da değerlendirilebilir. Sanat dallarına yönelik beğenileri toplumsal statü farklılıklarının ve eşitsizliklerin etkilediği ileri sürülebilir. Müzikal anlamın farklılıklar göstermesi; bir müzik parçasının bazı kişilerce beğenilirken, bazı kişilerce kötü ve değersiz olarak tanımlanması toplumsal statüye dayalı bir tercih olabilmektedir. Kişinin yaşadığı ve yetiştiği çevrenin, müzik beğenisinde ve tercihlerinde belirleyici olduğu söylenebilir. Yine, kişinin inancı ve benimsediği ideoloji ve yaşam biçimi de müzikal beğenisinde belirleyici olabilmektedir (Akkol, 2015, s. 311). Bundan dolayı bir müziğe karşı duyulan ilgi çoğu zaman bireysel zevk ve tercih olarak görülmekte ise de bireysel zevklerin ve tercihlerin, bireyin kimliğinin ve kişiliğinin bir sonucu olduğu da bilinmelidir (Sakar \& Maba, 2015, s. 994).

Yapılan çalışmalar, müzik tercihlerinin bireyin hem kendisini hem de bir başkasını nasıl görmek/görünmek istediğini belirleyen göstergeler olduğunu belirtmektedirler (Erdem, 2011, s. 21). Bundan dolayı müziğin dinlenme amacının, bireyi etkileme nedeninin, birey tarafından nasıl anlamlandırıldığının ortaya konması, müziğe ilişkin çok yönlü bir yol haritasının belirlenmesi açısından önemlidir. Bireylerin müziksel seçim ve tercihlerinin dışsal etkilere açık olması, birey için özdeşleşme davranışını önemli hale getirir. Çocukların model alma özellikleri, popüler müziği ve yıldızlarını kolayca model almalarına neden olabilmektedir. Müziksel sound, kullanılan müzik aletleri, müzisyenin giyimi, konuşması, tutum ve davranışları ile müziğe ilişkin daha birçok değişken, bireyin müzik türüne/türlerine ilgi duymasına ve o müziğin tüketicisi olmasına neden olabilmektedir. İnsanlar çoğu zaman müziği mesaj iletmede, kendilerini tanıma ve tanımlamada kullanabilmektedirler. Bu anlamda, müziğin bireyler için etki gücü yüksek bir iletişim ve etkileşim aracı olma özelliği taşıdığı söylenebilir.

Kapitalist anlayışın ileri teknoloji ve gelişmiş kitle iletişim araçları vasıtasıyla körüklediği küresel ölçeli popüler müzik sarmalı, bütün bireyleri olduğu gibi öğrencileri de etkisi altına almıştır. Okulun, çocukların birbirleriyle iletişim ve etkileşim halinde oldukları bir yer olma özelliği, çocukların birbirlerini birçok açıdan etkilemelerine ve 
yönlendirmelerine neden olabilmektedir. Bu etkilemeden ve yönlendirmeden çocukların müziğe dair ilgi ve bilgilerinin, müziğe yönelik alg1 ve tercihlerinin de etkilendiği bir gerçektir. Toplumsal yaşam ve iletişim olanakları, okullardaki çocukların müzik tercihlerindeki ayrışma ve benzeşmenin de alt yapısını oluşturabilmektedir.

Alanyazın incelendiğinde; Kılıç (2016) tarafından ortaokul öğrencilerinin müzik ile ilgili görüşlerinin incelendiği, Sakar ve Maba (2015) tarafından ortaokul öğrencilerinin müziksel tercihleri ve dinleme pratiklerinin araştırma konusu yapıldığı; Çiftçi (2010) tarafından popüler kültür, popüler müzik ve müzik eğitimi konulu çalışma yapıldığı; Erdal (2009) tarafından müzik türlerinin tercih edilmesinde kişilik özellikleri ve beğeni ilişkisinin mercek altına alındığı; Yağışan (2013) tarafından üniversite öğrencilerinin müzik tercihleri ve saldırganlıkla ilişkisinin konu edinildiği; Uluçay (2018) tarafından yapılan çalışmada lise öğrencilerinin dinledikleri müzik türlerinin şiddet eğilimlerine etkisinin irdelendiği; Ang1 (2013) tarafından müzik kavramı ve Türkiye'de dinlenen bazı müzik türlerinin araştırma konusu edildiği; Aydıner-Uygun (2015) tarafından öğretmen adaylarının geleneksel müzik türlerine ilişkin algılarının metaforlar aracılı̆̆ıyla incelendiği; Düzbastılar (2017) tarafından yapılan çalışmada ise müzik eğitiminin müzikal tercihler üzerindeki etkisin araştırıldığ anlaşılmaktadır. Ayrıca bireylerin müzik türü tercihleri ile kişilikleri, tutum ve davranışları (şiddet, saldırganlık, kaygı, bağımlılık vb.) arasındaki ilişkinin incelendiği çalışmaların da (Aydoğan \& Gürsoy, 2007; Devlin \& Seidel, 2009; Güner, 1998; Schwartz \& Fouts, 2003; Mills, 1996; Ögel, Sarp, Gürol, \& Ermağan, 2014; Scheel \& Westefeld, 1999; Sezer, 2011) alanyazında sıkça yer aldığı görülmektedir.

Popüler müziklerin dinleyiciye ulaşabilmek için video klipleri ve müzik kanallarını sık kullanmaları, tercih edilen müzik türü ile görsel ve işitsel medya arasında yakın bir ilişki olduğunu göstermektedir (Uluçay, 2018, s. 142). Amerika'da yapılan bir çalışmada gençlerin haftada ortalama 40 saat müzik dinledikleri ve günde ortalama 2 saat müzik kanalı izledikleri; müzik kanallarında yayınlanan kliplerin ortalama \%75'inde cinsellik ve seks içeren unsurlar ile şiddet, alkol ve sigara kullanımını özendirici görüntülerin bulunduğu sonucuna ulaşılmıştır (The American Academy of Pediatrics, 2009, s. 1489). Amerika'da yapılan ve birçok ülkede de benzer sorunların varlığına işaret eden bu sonuçlar, pediatristlerin, eğitimcilerin ve ailelerin çocukların müzik dinleme tercihleri noktasında işbirliği yapmalarının gerekliliğini ortaya koymaktadır. Gelişen medya ve iletişim teknolojisi sayesinde bireylerin müzik dinleme alışkanlıkları ve tercihleri müzik-video kliplerini izlemeyle birlikte artarak ve değişerek devam etmektedir. Bu süreç, dinlenen müzik türünün bireyler üzerindeki olumlu/olumsuz etkisini de artırmaktadır. Dinlediği müziğin yanında izlediği kliplerdeki görsel imgelerin de bireylerin gelişimi üzerindeki etkileri dikkate alındığında, ailelerin ve öğretmenlerin başta olmak üzere, bütün eğitim paydaşlarının bilinçlendirilmelerinin ve bir farkındalık yaratılmasının olumlu etkiler oluşturacağı düşüncesi bu araştırmanın yapılma gerekçelerinden birini oluşturmaktadır. Alışkanlıkların küçük yaşlarda oluşması, küçük çocukların dış etkilere ve yönlendirmelere daha açık olmaları ve model alma özelliklerinin daha gelişmiş olması, bu çalışmada ilkokul öğrencilerinin konu edinilmesinin nedenlerinden biridir. Ayrıca, müziğe yönelme ve müzik eğitimcisi olma düşüncesinin çoğu zaman ilkokul ve ortaokul yıllarında oluştuğu da bilimsel bir sonuçtur (Madsen \& Kelly, 2002, s.330).

Öğrencilerin müziğe yönelik beğenileri ve algıları okul ortamından, müzik derslerinden, öğretmenlerin müziğe ilişkin tutum ve davranışlarından, müzikle ilgili 
kişilerin ve öğretmenlerin kişiliğinden, kitaplardan, okul içinde veya dişında gerçekleştirilen müzik etkinliklerinden, yazılı, görsel ve işitsel medyadan etkilenebilmektedir. Çocukların müziğe ilişkin görüşlerinin tespit edilmesinin; onların müzik beğenilerini ve tercihlerini, müziğe ilişkin bilgi düzeylerini, müziğe yönelik tutum ve davranışların belirlemede; müzik eğitimine yönlendirilmelerinde, müzik eğitimi konusundaki karar verici mekanizmalara önemli bilgiler ve bakış açıları sunmada yararlı olacağı düşüncesi de bu çalışmanın yapılma gerekçelerinden bir diğerini oluşturmaktadır.

$\mathrm{Bu}$ çalışma, ilkokul öğrencilerinin müzik türü tercihlerini, bu tercihlerinin nedenlerini ve tercih ettikleri müzik türünün faydasına ilişkin düşüncelerini belirlemeyi; velilerin ve öğretmenlerin öğrencilerin müzik türü tercihlerine bakışlarını, tercih edilen müzik türünün faydasına ilişkin görüşlerini ve en çok tercih edilen müzik türünü nasıl tanımladıklarını eğitimsel ve sosyolojik açıdan ortaya koymayı amaçlamaktadır. Popüler kültürün ve popüler müzik türlerinin yükselişinin neden ve sonuçları ile olumlu ve olumsuz yönleri de bu çalışmada değinilen konular arasındadır. Bu çalışmada, belirtilen temel amaçlar doğrultusunda aşağıdaki sorulara yanıt aranmıştır:

1. Öğrenciler hangi müzik türlerini tercih etmektedirler?

2. Öğrencilerin müzik türü tercihlerini belirleyen etmenler nelerdir?

3. Öğrenciler tarafından en çok tercih edilen müzik türlerine ilişkin öğrenci, öğretmen ve veli görüşleri nelerdir?

4. Öğrenciler tarafından en çok tercih edilen müzik türlerinin tanımlanmasına/değerlendirilmesine ilişkin öğretmen ve veli görüşleri nelerdir?

\section{YÖNTEM}

\section{Araştırma Modeli}

İlkokul öğrencilerinin müzik türü tercihlerini, bu tercihlerinin nedenlerini ve tercih ettikleri müzik türünün faydasına ilişkin düşüncelerini belirlemeyi; velilerin ve öğretmenlerin öğrencilerin müzik türü tercihlerine bakışlarını, tercih edilen müzik türünün faydasına ilişkin görüşlerini ve en çok tercih edilen müzik türünü nasıl tanımladıklarını ortaya koymayı amaçlayan bu çalışmada nitel araştırma desenlerinden fenomenolojik (olgubilim) desen kullanılmıştır. Olgubilim deseni, farkında olunan ancak hakkında detaylı bir bilgiye ve anlayışa sahip olunmayan olgulara yoğunlaşır (Yıldırım \& Şimşek, 2018).

\section{Çalışma Grubu}

Araştırmanın çalışma grubunu, 2019-2020 öğretim yılında Ordu ilindeki ilkokullarda öğrenim gören 27 ilkokul dördüncü sınıf öğrencisi, 12 sınıf öğretmeni ve 27 öğrenci velisi oluşturmaktadır. Çalışma grubundaki öğrencilerin 12'si $(\% 44,45)$ kız, 15'i $(\% 55,55)$ erkek; öğretmenlerin 5'i $(\% 41,66)$ kadın, 7'si $(\% 58,34)$ erkek; öğrenci velilerinin ise 14'ü kadın $(\% 51,85), 13$ 'ü $(\% 48,15)$ erkektir. Çalışma, 3 ilkokulda gerçekleştirilmiştir. Okullar, okulun bulunduğu yerleşim yerinin idari yapısı (il, ilçe, köy) dikkate alınarak gruplandırılmış ve her gruptan Ordu İl Milli Eğitim Müdürlüğünün stratejik planında en başarılı olarak belirlenmiş olan bir okul seçilmiştir. Dördüncü sınıf öğrenci mevcutlarına bağlı olarak il merkezindeki okuldan 12, ilçe merkezindeki okuldan 9, köyde bulunan okuldan ise 6 öğrenci örneklem olarak seçilmiştir. Katılımcı öğretmenler, veliler ve öğrenciler amaçlı örnekleme yöntemlerinden ölçüt örnekleme yöntemiyle belirlenmiştir. Ölçüt örnekleme yöntemi, örneklemin problemle ilgili olarak belirlenen niteliklere sahip kişiler, olaylar, nesneler veya 
durumlardan oluşturulmasıdır (Büyüköztürk, Akgün, Karadeniz, Demirel, \& Çakmak, 2018). İlkokul dördüncü sınıfta okuyor olmak ve sınıfın akademik başarı sıralamasında ilk üçe girmek öğrenci seçme ölçütü; ilkokul dördüncü sınfı okutmak ve sınıfından araştırmaya öğrenci seçilmiş olması öğretmen seçme ölçütü; çocuğunun araştırma için seçilmiş olması veli seçme ölçütü olarak belirlenmiştir.

\section{Veri Toplama Araci}

Araştırmaya başlamadan önce, katılımcıların müzik türleri hakkında bilgi sahibi olmaları sağlanmıştır. Bu amaçla, okullardaki bilgisayarlar ve etkileşimli tahtalar kullanılarak katılımcılara müzik türlerinin en bilinen şarkıları/örnekleri dinletilmiş, klibi/videosu bulunan şarkıların klipleri/videoları izletilmiş ve araştırmacı tarafından müzik türleri hakkında kısa açıklamalar yapılmıştır. Müzik türlerini tanıtmadaki amaç, çocukların dinledikleri müziklerin türlerini belirleyebilmelerini (dinledikleri müziklerin hangi türe girdiğini anlamalarını) kolaylaştırmaktır.

Araştırma verileri, yarı yapılandırılmış anket ve yarı yapılandırılmış görüşme formuyla toplanmıştır. Veri toplama araçları araştırmacı tarafından geliştirilmiştir. Yarı yapılandırılmış anket, "Dinlemeyi en çok tercih ettiğiniz müzik türü nedir?", "Bu müzik türünü tercih etme nedeniniz nedir?", "Dinlediğiniz müzik türünü faydalı buluyor musunuz?" sorulardan oluşturulmuştur. Anket uygulanması sonucunda okul şarkılarının $\% 2,79$ gibi düşük bir oranda tercih edildiğinin ortaya çıması üzerine, bu konu araştırmaya değer bulunmuş ve öğrencilere okul şarkılarını tercih etmeme nedenlerine ilişkin olarak "Okul şarkılarını dinlemeyi tercih etmemenizin nedeni nedir?" şeklinde yeni bir soru sorulmuştur. Veri toplama aracının anlaşılabilirliğini test etmek amaciyla 15 ilkokul dördüncü sınıf öğrencisine ön uygulama yapılmış ve ön uygulama sonucunda ankete son şekli verilmiştir.

Görüşmelerde, konuyla ilgili daha derinlemesine bilgi edinebilmek için öğrencilere müzik türü tercihlerine, bu tercihin nedenlerine, dinledikleri müzik türünün kendileri için faydalı olup olmadığına ve okul şarkılarının dinlenme oranının azalmasının nedenlerine ilişkin sorular sorulurken; öğretmenlere ve velilere ise öğrenciler tarafından tercih edilen müzik türünün öğrenciler için faydalı olup olmadığına ve tercih edilen müzik türlerini nasıl tanımladıklarına/değerlendirdiklerine ilişkin sorular sorulmuştur. Yarı yapılandırılmış görüşme formları belli sorulardan oluşmakta ve katılımcılar bu sorulara verdikleri cevaplarla kendi kişisel görüşlerini belirtmektedirler (Yıldırım \& Şimşek, 2018). Görüşme soruları hazırlanırken araştırmanın amacına uygun olmasına ve anlaşılabilir olmasına özen gösterilmiştir. Konu uzmanı 2 öğretim üyesinin, 4 sınıf öğretmeninin, 3 müzik öğretmenin ve 2 velinin görüş ve önerileri doğrultusunda görüşme formuna son şekli verilmiştir.

\section{Verilerin Toplanması}

Veri toplama araçlarından yarı yapılandırılmış anket katılımcı öğrencilere dağıtılarak araştırmacının gözetiminde cevaplanması sağlanmıştır. Anketin cevaplama süresi yaklaşık 8 dakika olarak belirlenmiştir. Müzik türü tercihlerine, bu tercihin nedenlerine, tercih ettikleri müzik türünün faydasına ve okul şarkılarının dinlenme oranının azalmasının nedenlerine ilişkin soruların sorulduğu öğrenci görüşmeleri için yaklaşık 15 dakika; öğrenciler tarafından tercih edilen müzik türünün faydasına ve tercih edilen müzik türlerini nasıl tanımladıklarına/değerlendirdiklerine ilişkin soruların sorulduğu öğretmen ve veli

SEFAD, 2020; (44): 355-378 
görüşmeleri için ise yaklaşık 10 dakika ayrılmıştır. Bütün görüşmeler, okul yöneticileri tarafından sağlanan bir odada gerçekleştirilmiştir.

Çalışmada, Yükseköğretim Kurumları Bilimsel Araştırma ve Yayın Etiği Yönergesinde belirtilen etik ilkelere titizlikle uyulmuş; bu amaçla Mardin Artuklu Üniversitesi'nden 22.07.2020 tarihli ve 34233153-050.06.04-06-03 sayılı Etik Kurulu Kararı alınmıştır. Araştırma ile ilgili olarak ilgili kurumlardan araştırma için izin alınmış, katılımcılar araştırma konusunda detaylı olarak bilgilendirilmiş ve bilgilendirilmiş onam formu imzalatılmıştır. Araştırma sürecinde katılımcıların biyolojik, psikolojik, sosyolojik ve hukuksal varlıklarını korumak ve özgün iradelerine saygı göstermek birinci öncelik olarak belirlenmiş ve araştırmaya katılmada gönüllülük esas alınmıştır. Araştırma sürecinde izin almak suretiyle katılımcıların ses kaydı yapılmış ve notlar tutulmuştur. Araştırma için sağlanan mekânlar, imkânlar ve cihazlar amaç dışı kullanılmamış; kişi ve kurumlardan temin edilen veri ve bilgiler, izin verildiği ölçüde ve şekilde kullanılmış, bu bilgilerin gizliliğine azami riayet edilmiş ve bilgiler hassasiyetle korunmuştur. Araştırma sürecinde katılımcılar hiçbir şekilde yönlendirilmemiş ve araştırmacı yansızlığı azami derecede korumuştur. Çalışma etiği ve ahlaki açıdan uygun olmayacağı düşüncesiyle, katılımcıların gerçek isimleri kullanılmamış; öğrenci isimleri Öğrenci 1, Öğrenci 2,... Öğrenci 27, öğretmen isimleri Öğretmen 1, Öğretmen 2, ... Öğretmen 12, veli isimleri ise Veli 1, Veli 2,... Veli 27 şeklinde kodlanmıştır.

\section{Verilerin Analizi}

Araştırmada, yarı yapılandırılmış anketle elde edilen veriler, betimsel analiz yöntemiyle analiz edilmiştir. Katılımcıların her soruya vermiş oldukları cevaplar puanlanarak sayısal verilere dönüştürülmüş, daha sonra her bir maddenin yüzde oranı hesaplanmıştır. Görüşme yoluyla elde edilen nitel veriler, içerik analizine tabi tutularak cevapların benzerlikleri ve yakınlıkları dikkate alınmak suretiyle kategorilere/temalara göre kodlanmıştır. Ardından, belirlenmiş olan kategorilerin yüzdelik oranları hesaplanmak suretiyle veriler nicelleştirilerek (sayısallaştırılarak) analiz edilmiştir. Nitel verinin nicelleştirilmesi; görüşme, gözlem ya da doküman incelemesi yoluyla elde edilen verilerin, belli süreçlerden geçirilerek sayılara ya da rakamlara dökülmesidir (Yıldırım \& Şimşek, 2018).

Yapılan hesaplamalar sonucunda elde edilen bulgular tablolara dönüştürülerek sunulurken; görüşme yapılan bireylerin görüşlerinden yer yer doğrudan alıntılar da yapılmıştır. Verilerin analizi sonucunda ulaşılan bulgular sistematik, mantıklı, tutarlı ve anlaşılır bir şekilde düzenlenerek araştırmanın amacı ve alt amaçları doğrultusunda sunulmuştur. 


\section{BULGULAR}

Öğrencilerin Müzik Türü Tercihlerine İlişkin Bulgular

Öğrenciler tarafından tercih edilen müzik türlerine ilişkin bulgular Tablo 1'de sunulmuştur.

Tablo 1. Öğrenciler Tarafından Tercih Edilen Müzik Türleri

\begin{tabular}{lccc}
\hline Müzik Türleri & K1z & Erkek & Toplam \\
\hline Hiphop-Rap & 36,29 & 31,29 & 33,45 \\
Türkçe Pop & 16,94 & 23,31 & 20,56 \\
Yabancı Pop & 22,58 & 15,34 & 18,47 \\
Rock & 12,10 & 17,79 & 15,33 \\
Türk Halk Müziği (THM) & 2,42 & 3,07 & 2,79 \\
Okul Şarkıları/müziği & 4,03 & 1,84 & 2,79 \\
Arabesk-fantezi & 1,61 & 2,45 & 2,09 \\
Türk Sanat Müziği (TSM) & 1,61 & 1,23 & 1,39 \\
Özgün Müzik & 0,81 & 1,84 & 1,39 \\
Tasavvuf Müziği & 0,81 & 1,23 & 1,05 \\
Klasik Müzik & 0,81 & 0,61 & 0,70 \\
\hline
\end{tabular}

Tablo 1 üzerinde yapılan incelemede, kız öğrenciler başta olmak üzere, öğrencilerin en fazla Hiphop-Rap müzik türünü tercih ettikleri, bu türü Türkçe Pop, Yabancı Pop ve Rock türlerinin takip ettiği, bütün öğrenciler tarafından en az tercih edilen müzik türünün Klasik müzik türü olduğu; okul şarkılarının ise erkek öğrenciler başta olmak üzere bütün öğrenciler tarafından az tercih edilen bir müzik türü olduğu görülmektedir.

\section{Öğrencilerin Müzik Türü Tercihlerini Belirleyen Nedenlere İlişkin Bulgular}

Öğrencilerin müzik türlerini tercih etme nedenleri ile okul şarkılarını az tercih etme nedenlerine ilişkin bulgular Tablo 2 ve Tablo 3'te sunulmuştur.

Tablo 2. Öğrencilerin Müzik Türlerini Tercih Etme/Dinleme Nedenleri

\begin{tabular}{lccc}
\hline Dinleme Nedenleri & Kiz & Erkek & Toplam \\
\hline Herkes dinliyor & 33,06 & 34,36 & 33,80 \\
Kliplerini seviyorum & 16,56 & 18,55 & 17,42 \\
Sanatçı1 seviyorum & 15,32 & 15,34 & 15,33 \\
Eğlenceli & 14,52 & 11,56 & 12,89 \\
Kardeşim dinliyor & 7,26 & 9,20 & 8,36 \\
Komik & 5,65 & 6,13 & 5,92 \\
Sözleri güzel & 4,03 & 6,13 & 5,23 \\
Duygusal & 1,61 & 0,61 & 1,05 \\
\hline
\end{tabular}

Tablo 2 üzerinde yapılan incelemede, kız ve erkek öğrenciler arasında küçük farklar olmakla birlikte, öğrencilerin müzik türlerini tercih etmelerinde bu türün yaygın olarak dinlenmesinin birinci derecede etkili olduğu; sırasıyla, klibinin ve sanatçısının sevilmesinin, eğlenceli olmasının, diğer aile bireyleri tarafından dinleniyor olmasının, komik bulunmasının, sözlerinin güzel olmasının ve duygulara hitap etmesinin de müzik türünün tercih edilmesinin diğer nedenleri olduğu görülmektedir. 
Tablo 3. Okul Şarkılarının Tercih Edilmeme Nedenleri

\begin{tabular}{lccc}
\hline Nedenler & K1z & Erkek & Toplam \\
\hline Kimse dinlemiyor & 26,61 & 25,77 & 24,04 \\
Hiçbir yerde çalmıor & 25,00 & 24,54 & 22,65 \\
Arkadaşlarım dalga geçer & 22,58 & 22,09 & 19,86 \\
Çocuk şarkısı & 17,74 & 18,40 & 15,68 \\
Sevmiyorum & 12,90 & 14,11 & 11,15 \\
Güzel değil & 8,06 & 9,20 & 6,62 \\
\hline
\end{tabular}

Tablo 3 üzerinde yapılan incelemede, kimse tarafından dinlenmemesinin okul şarkılarını tercih edilmeme/dinlememe nedenlerinin başında yer aldığı; hiçbir yerde çalmamasının, arkadaşlar arasında alaya alınma korkusunun, şarkıların çocukça olarak nitelendirilmesinin, şarkıların sevilmemesinin ve güzel olmamasının okul şarkılarının tercih edilmeme/dinlenmeme nedenleri arasında sayıldığı görülmektedir. Öğrencilerin müzik türlerini tercih etme nedenleri ile okul şarkılarını az tercih etme nedenlerine ilişkin açıklamalarından bazı örnekler aşağıda sunulmuştur:
"En çok Hiphop-Rap müziği seviyorum. Çünkü herkes bu müziği dinliyor. Bu müzik moda" (Öğrenci 5).
"Benim Hiphop-Rap müzik dinlememin nedeni aslnda klipleridir. Bu müziğin videolarını çok seviyorum. Bana çok değ işik geliyor" (Ö̆̆rrenci 9).
"Hiphop-Rap müzik sanatçllarmın kıyafetleri ve hareketleri çok hoşuma gidiyor" (Öğrenci 8).
"Abim hangi müziği dinlerse ben de o müziği dinlerim. Çünkü abimi çok beğeniyorum" (Öğrenci 12).
"Okul şarkıları televizyonda çıkmıyor. Klibi de olmadı̆̆ı için bu şarkıları dinlemiyorum" (Öğrenci 21).
"Okul şarklları bana çocukça geliyor. Okul şarkılarının modası da geçti zaten" (Öğrenci 17).
"Okul şarkiların dinlersem herkes benimle alay eder. Bu şarkıları sadece müzik dersinde söylüyoruz" (Ö̈̆renci 24).

\section{Tercih Edilen Müzik Türünün Faydasına İlişkin Bulgular}

Öğrenciler tarafından en çok tercih edilen müzik türlerine ilişkin öğretmen, veli ve öğrenci görüşleri Tablo 4 'te sunulmuştur.

Tablo 4. Öğrenci, Öğretmen ve Velilerin Tercih Edilen Müzik Türlerine İlişkin Görüşleri

\begin{tabular}{lccc}
\hline Düşünceler & Öğretmen & Veli & Öğrenci \\
\hline Kötü/faydasız & 77,27 & 65,52 & 17,42 \\
İyi/faydalı & 13,64 & 20,69 & 68,99 \\
Kararsız & 9,09 & 13,79 & 13,59 \\
\hline
\end{tabular}

Tablo 4 üzerinde yapılan incelemede, öğretmen ve velilerin öğrenciler tarafından en çok tercih edilen müzik türlerini kötü ve faydasız olarak nitelendirdikleri, öğrencilerin ise öğretmen ve velilerin aksine tercih ettikleri müzik türlerini iyi ve faydalı olarak 
değerlendirdikleri görülmektedir. Öğrenciler tarafından en çok tercih edilen müzik türlerine ilişkin öğretmen, veli ve öğrenci görüşlerinden bazı örnekler aşağıda sunulmuştur:

"Hiphop-Rap gibi müzik türlerinin çocuklara hiçbir fayda sağlamadığını düşünüyorum. Bu müzikler zihinsel açıdan çocuklara birşey katmadıkları gibi hafızalarım da gereksiz şeylerle doldurmalarına neden olmaktadırlar" (Öğretmen 1).

"Popüler müzik türlerinin neredeyse tamamı öğrencilere zarar verici unsurlar içermektedirler. Bu müzik türü, manevi yönden öğrencileri çok olumsuz yönlere itmektedir." (Öğretmen 11).

"Popüler müzik türlerinin çocuklara akademik, psikolojik ya da sosyal yönden olumlu bir şey kattıklarını sanmıyorum." (Öğretmen 9).

"Bence popüler müzik türleri, içeriklerinden dolayı çocuklara çok zarar vermektedirler. Çünkü bu müzikler ahlaki yönü çok zayıf müziklerdir (Veli 13).

"Bu müzikler çocukları kötü tutum ve davranışlara yönlendirmektedir. Toplumdaki milli ve manevi değerlere zarar veren müziklerdir bunlar" (Veli 22).

"Hiphop-Rap ve diğer müzik türleri hem sözlerinden, hem sanatçısından hem de kliplerinden dolayı çocuklara kötü örnek olmaktadır. Bu müzikler geleneksel Türk aile yapısını parçalamaya çalışmaktadırlar" (Veli 25).

"Hiphop-Rap müzikleri beni rahatlatıyor. Bu müzikler beni eğlendiriyor" (Öğrenci 3).

“Hiphop-Rap müziklerin faydalı olduğuna inanıyorum. Çünkü bu müzikler sayesinde hızlı konuşmayı öğreniyoruz" (Öğrenci 21).

"Bu müzikler faydall, çünkü bu müzikler sayesinde arkadaş grubumuz oluşuyor" (Öğrenci 25).

Öğrenciler tarafından en çok tercih edilen müzik türlerine ilişkin öğretmen, veli ve öğrenci görüşlerinden yapılan alıntılar; velilerin ve öğretmenlerin bu müzik türlerini ahlaki seviyeyi düşürmesi, akademik getirisi olmaması, sosyal yönden uygunsuz ilişkilere neden olmaları, öğrenci psikolojisini olumsuz etkilemeleri, milli ve manevi değerleri yozlaştırmaları, geleneksel Türk aile yapısına aykırı olmaları yönünden faydasız bulduklarını ortaya koymaktadır. Ayrıca, konu Tablo 5'te yer alan bilgilerle bir bütün olarak değerlendirildiğinde; öğretmenlerin ve velilerin öğrencilerin en çok tercih ettikleri müzik türlerinin asilik, argo, cinsellik, şiddet, madde bağımlılı̆̆ı ve istismar gibi olumsuz durumları içermelerinden de rahatsız oldukları anlaşılmaktadır. Görüşmelerden yapılan alıntılarda öğrencilerin ise öğretmenlerinin ve velilerinin aksine, tercih ettikleri müzik türlerini rahatlamalarını ve eğlenmelerini sağlaması, arkadaş grubuna girmelerine ortam hazırlaması, hızlı konuşma yeteneklerini geliştirmesi gibi yönlerden faydalı bulduklarını ortaya koymaktadır. 


\section{Öğrenciler Tarafından Tercih $\quad$ Edilen $\quad$ Müzik $\quad$ Türlerinin Tanımlanmasına/Değerlendirilmesine İlişkin Bulgular}

Öğrenciler tarafından en çok tercih edilen müzik türlerine ilişkin öğretmen ve veli tanımlamaları/değerlendirmeleri Tablo 5 'te sunulmuştur.

Tablo 5. Öğretmenlerin ve Velilerin Öğrenciler Tarafından Tercih Edilen Müzik Türlerine İlişkin Tanımlamaları/Değerlendirmeleri

\begin{tabular}{lcc}
\hline Düşünceler & Öğretmen & Veli \\
\hline Asilik & 31,82 & 27,59 \\
Argo & 22,73 & 24,14 \\
Cinsellik & 18,18 & 10,34 \\
Şiddet & 13,64 & 31,03 \\
Madde bağımlılı̆̆ & 9,09 & 3,45 \\
İstismar & 4,55 & 3,45 \\
\hline
\end{tabular}

Tablo 5 üzerinde yapılan incelemede; öğretmenlerin ve velilerin, öğrenciler tarafından en çok tercih edilen müzik türlerini asilik, argo, cinsellik, şiddet, madde bağımlılığ istismar gibi olumsuz metaforlarla tanımladıkları görülmektedir. Öğrenciler tarafından en çok tercih edilen müzik türlerine ilişkin öğretmen ve veli tanımlamalarına/değerlendirmelerine ilişkin bazı örnekler aşağıda sunulmuştur:

\footnotetext{
"Hiphop-Rap gibi müzik türlerinin cinsellik içerdiği, bu tür müziklerde argo sözcüklerin ve hatta küfre varan sözlerin çokça yer aldı bir gerçektir" (Öğretmen 2).

"Hiphop-Rap gibi müzik türleri çocukları asileştirmekte, okulda disiplini, toplumda ise düzeni bozmaktadır. Bu müzikler kuralsız yaşantıyı özendirmektedir" (Öğretmen 9).

"Popüler müzik türleri isyankâr bir kuşağın, tahammülsüz ve saldırgan bir gençliğin yetişmesinde neden olmaktadır" (Öğretmen 12).

"Hiphop-Rap ve benzeri müzikler genel Türk ahlak anlayışına aykırıdır. Bu müzikler argoyu ve cinselliği kutsamakta, şiddeti vurgulamakta, bağımlılı̆̆ özendirmektedir" (Öğretmen 1).

"Bu müzik türlerinin çocukları şiddet eğilimli hale getirdiğini söyleyebilirim. Bu müziklerin sözleri de klipleri de kavga, şiddet, kırma ve dökme yoğunlukludur" (Veli 5).

"Popüler müzik türleri öğrencileri asileştirmekte, anne-babaya, öğretmene ve diğer büyüklere saygıyı ortadan kaldırmaktadır" (Veli 18).

"Popüler müzik türleri hem sanatçısı hem de klipleriyle istismarı özendirmekte, ahlaksızlı̆̆ı yaygınlaştırmakta, alkol ve madde bağımlılığını teşvik etmektedir" (Veli 13).

“Öğrencileri yanlış yollara yönlendiren bu müzikler yasaklanmalıdır bence” (Veli 20).
}

\section{TARTIŞMA}

Araştırmada Hiphop-Rap müzik türünün öğrenciler tarafından en çok tercih edilen müzik türü olduğu; bu türü ise Türkçe Pop, Yabancı Pop ve Rock türünün takip ettiği, Türk Halk Müziği (THM), Arabesk-fantezi, Türk Sanat Müziği (TSM), Özgün Müzik ve Tasavvuf Müziğinin benzer oranlarda az tercih edilen müzik türleri olduğu, bütün öğrenciler tarafından en az tercih edilen müzik türünün Klasik Müzik olduğu; okul şarkılarının ise erkek öğrenciler başta olmak üzere bütün öğrenciler tarafından az tercih edilen bir müzik türü olduğu anlaşılmaktadır. Sakar ve Maba (2015) tarafından yapılan çalışmada da, 
öğrenciler tarafından en çok tercih edilen müzik türünün Hiphop-Rap olduğu sonucuna ulaşılmıştır. Bozkurt, Zahal ve Uyan (2015) tarafından yapılan çalışmada, öğrencilerin Hiphop-Rap müzik türünü yüksek oranda tercih ettikleri tespit edilmiştir. Taşal ve Vural (2011) yaptıkları çalışmada, öğrencilerinin en çok Hiphop-Rap ve Pop Müzik dinlediklerini, diğer müzik türlerini ise fazla tercih etmediklerini belirtmişlerdir. Yağışan (2013) ve Düzbastılar (2017) tarafından yapılan çalışmalarda, öğrencilerin en çok tercih ettikleri müzik türünün Pop Müzik olduğu tespit edilmiştir.

Hiphop-Rap müzik türü 1970'li yıllarda önce Amerika'nın varoşlarında ortaya çıkmış, 1980'lerde Fransa ve Almanya'da popülerlik kazanmış ve buralardan tüm dünyaya yayılmıştır. Hiphop-Rap, 1970'li yılların sonunda Amerika'da kötü koşullarda ve azınlık olarak yaşayan zencilerin gündemden uzaklaşmak ve eğlenmek için oluşturduğu bir kültür ve yaşam tarzıdır (Ang1, 2013). Hiphop-Rap, Amerika'nın gettolarında yaşayan ve sosyoekonomik olarak sistemlerin adaletlerinden yoksun olan gençlerin kendilerini ifade etme ve tepki gösterme aracı olarak ortaya çıkmış; II. Dünya Savaşı sonrası işçi göçleriyle kozmopolit bir yapıya sahip olan Almanya'daki göçmen gençler tarafından sahiplenilmiş ve karşı karşıya kaldıkları ırkçılık ve ayrımcılık gibi sorunları dillendirmedeki araçları haline gelmiştir. Rap müzik, 2000'lerin ortalarından itibaren jenerik müzikleri Rap olan dizi ve filmler, çeşitli kültürel organizasyonlar, festivaller ve başka müzik tarzlarından önemli sanatçılarla düetler gibi pek çok kırılma ile mevcut kemik kitlesinin dışında başka çevreleri de varlığından haberdar etmiş ve kendisini dinleterek piyasada var olmayı başarmıştır (Çakmak, 2018).

Hiphop-Rap müzik türünün öğrenciler tarafından en çok tercih edilen müzik türü olmasının birçok nedeni bulunmaktadır. Bu müzik türünün öğrenciler arasında yaygınlaşmasının Türkiye'ye özgü bir sonuç olmadığı, bu sonuçta bu müzik türüne ilişkin olarak tüm dünyada yakalanan yükseliş trendinin de etkili olduğu söylenebilir. Teknolojik gelişmeler ve internetin yaygınlaşması dinleyicinin şarkılara, kliplere ve videolara kurumsal bir yayın organına gereksinim duymadan hızlıca ulaşabilmelerini sağlamaktadır. Hem müziği üretene hem de tüketene pek çok kolaylık sağlayan bu durumun, Hiphop-Rap gibi popüler müzik türlerinin dünyada popülerleşmesini ve eş zamanlı olarak Türkiye'de de kendine yer edinmesini sağladığı söylenebilir (Çakmak, 2018). Yaşları itibariyle küçük olmakla birlikte, ilkokul öğrencilerinin de farklı nedenlerle kızdıkları, sevmedikleri, karşı çıtıkları, hatta isyan ettikleri durumlarla karşılaştıkları, bu anlamda farklı deneyimler yaşadıkları bilinmektedir. Müziğin, bireylerin yaşadıklarını dışarı vurmalarını sağlayan yapısının da bu türün dinlenme oranını artırdığı söylenebilir. Ayrıca, bazı ailelerin, okulların ve diğer kurumların içinde bulunduğu antidemokratik ortam ve bireylerin kendini ifade etme özgürlügünün sınırlandırılmış olması da Hiphop-Rap müziğin tercih edilme nedenleri arasında sayılabilir. Çünkü Rap müzik, insanların söylemek isteyip de söyleyemediği, düşünmekten korktuğu ya da vazgeçtiği veya duymak istemediği pek çok fikri ve sözü kitlelerin kulağına fısıldayan özgürlükçü bir müzik türüdür (Çakmak, 2018).

İlkokul öğrencilerinin, içinde yaşadıkları toplumum sorunlarından ve yaşanan süreçlerden soyutlanmış bireyler oldukları söylenemez. Dolayısıyla, toplumların yaşadıkları sorunlar ve süreçler gençlerin ve diğer yetişkinlerin yaşam tarzlarına ve müziklerine yansıdığı gibi çocukların da müzik türü tercihlerine yansıyabilmektedir. Çünkü bireyin içinde yaşadığı genel çevresi ile müziksel çevresi etkileşim yoluyla birbirini etkiler ve bütünler (Çiftçi, 2010, s. 159). Bedir ve Akkurt'a (2012) göre, çocuklar çok küçük yaşlarda 
müzik dinlemeye başlamakta ve zamanla yaşadıkları deneyimlerle kendi müzik tarzlarını oluşturmaktadırlar.

Araştırmada, öğrenciler tarafından en az tercih edilen müzik türünün klasik müzik türü olduğu sonucuna ulaşılmıştır. Bu durum, öğrencilerin gerek ailelerinin ve gerekse içinde yaşadıkları toplumum kültürel yapısının klasik müzik dinlemeye fazla yatkın olmamasıyla ve bu müzik türünün kitle iletişim araçlarında yaygın bir şekilde yer bulmamasıyla açıklanabilir. Ayrıca bu oranın azlığında eğitim sistemimizin de etkili olduğu söylenebilir. Türk Eğitim Sisteminin sinav merkezli olması, müzik derslerinin ve müzik eğitiminin önemsizleşmesi sonucunu doğurmuştur denebilir. Bu sonucun, diğer müzik türlerinin dinlenmesini ve öğrenilmesini olumsuz etkilediği gibi klasik müziğin de tanınma, sevilme ve dinlenme oranını azalttı̆̆ı söylenebilir. Ayrıca, ülkemizde verilmekte olan müzik eğitiminin ve bu eğitim sürecinde müzik türlerinin kaliteli ve güzel örneklerine yeterince yer verilememesinin de bu sonuçta etkili olduğu söylenebilir. Çocuklar tarafından müziğin şarkı söyledikleri, dans edip oyun oynadıkları bir faaliyet olarak algılanmasının da daha yavaş bir ritme sahip olan ve genelde sözlü olmayan klasik müziğin tercih edilme oranını azalttığı söylenebilir. Ayrıca, diğer müzik türlerine göre daha karmaşık bir yapıya sahip olan klasik müzik dinlemenin, bir olgunluk ve entelektüel düzey gerektirdiği de bilinmektedir (Erdal \& Ok, 2012, s. 72). Yağışan (2013, s. 111) tarafından yapılan çalışmada öğrencilerin klasik müzik dinleme alışkanlıklarının son derece yetersiz olduğu tespit edilirken; Ulutürk (2008) tarafından yapılan çalı̧̧mada ise öğrencilerin klasik müzik türünü tercih etmedikleri sonucuna ulaşılmıştır. Artemiz (2009, s. 53) tarafından yapılan çalışmada, hem kız hem de erkek öğrencilerin klasik müziğe olan ilgilerinin son derece düşük olduğu tespit edilmiştir. Asıl ilgisini popüler kültüre ve popüler müziğe yönlendirmiş olan çocukları tatlı sözlerle kandırıp klasik müzik aşığı yapmaya çalışmanın gereksiz bir çaba olduğunu da söylemek gerekir. Bu durumda müzik öğretmenlerinin yapmaları gereken, müzikte teknik bir uzman olarak öğrencilerine kültürel mirası aktarmak ve öğrencilerin kendilerine ait genellikle renkli değerler dizisine zorla müdahale etmek yerine, daha somut ve daha iletişimsel bir dil kullanarak, onu daha kullanışlı bir şekilde geliştirmek olmalıdır (Sakar, 2009, s. 392).

Araştırmada, kız ve erkek öğrenciler arasında küçük farklar olmakla birlikte, öğrencilerin müzik türlerini tercih etmelerinde türün yaygın olarak dinlenmesinin birinci derecede etkili olduğu; klibinin ve sanatçısının sevilmesinin, eğlenceli olmasının, diğer aile bireyleri tarafından dinleniyor olmasının, komik bulunmasının, sözlerinin güzel olmasının ve duygulara hitap etmesinin etkili olduğu görülmektedir. Müzik türünün çocukların ifadesiyle herkes tarafından dinleniyor olması, çocuklar tarafından da dinlenme/tercih edilme gerekçesini oluşturmaktadır. $\mathrm{Bu}$ durum, çocukların toplumsal etkilere açı oluşlarıyla, merak duygularının gelişmiş olmasıyla, toplumda yaygın olan bir tutum ve davranışı taklit etme özellikleriyle, beğendikleri kişileri rol-model almalarıla ve herkesten biri olma, bir gruba ait olma duygusuyla açıklanabilir. Kaldı ki popüler müzikler, birey açısından belli bir gruba ait olmanın simgesi olarak kabul edilmektedir (Aksu, 2008, s. 22). Bir katılımcının "En çok Hiphop-Rap müziği seviyorum. Çünkü herkes bu müziği dinliyor. Bu müzik moda." sözleri de açıklamalarımızı destekler niteliktedir.

Müzik türünün tercih edilmesinde klibinin ve sanatçısının sevilmesi, çocuklardaki görsel imgelere ve medyatik kişilere olan ilgi ile açıklanabilir. Kliplerde kullanılan görsel materyallerin çeşitliliği, sanatçının giyim tarzı ve davranışları bu yaş çocuklarının tercihlerini belirleyici güce sahiptir. Bir katılımcının "Benim Hiphop-Rap müzik dinlememin 
nedeni aslında klipleridir. Bu müziğin videoların çok seviyorum. Bana çok değişik geliyor." sözleri ile bir diğer katılımonın "Hiphop-Rap müzik sanatçılarının kıyafetleri ve hareketleri çok hoşuma gidiyor." sözleri araştırma bulgularımızı destekler niteliktedir. Ayrıca, teknolojik gelişmelerin ve internetin yaygınlaşmasının bir sonucu olarak müziklere, kliplere ve videolara ulaşmanın kolaylaşması da bu öykünme ve beğenme sürecini hızlandırmaktadır. Çünkü tercih edilen müzik türü ile görsel medya arasında sıkı bir ilişki görülmekte, popüler müzikler dinleyiciye ulaşabilmek için klipleri ve müzik kanallarını etkili olarak kullanmaktadırlar (Uluçay, 2018, s. 142). Yapılan bir çalışmada, öğrenciler tarafından en sık kullanılan müzik dinleme araçlarının başında cep telefonunun geldiği, bu aracı bilgisayar ve televizyonun takip ettiği tespit edilmiştir (Sakar \& Maba, 2015, s. 989).

Eğlenceli olma özelliği de öğrencilerin müzik türü tercihlerini belirlemede önemli bir rol oynamaktadır. Çünkü çocuklar tarafından müzik, şarkı söyledikleri, dans edip oynadıkları bir faaliyet olarak algılanmaktadır (Aksu, 2008). Bireyler genelde rahatlamak ve eğlenmek için müzik dinlemektedirler (Düzbastılar, 2017, s. 1486). Kılıç (2016) tarafından yapılan çalışmada, öğrencilerin önemli bir kısmının müziğin bir eğlence aracı olduğunu belirttikleri görülmüştür. Sakar ve Maba (2015) tarafından yapılan çalışmada, çocukların müzik dinleme amaçları arasında eğlence unsurunun önemli bir yer tuttuğu tespit edilmiş̧ir. Bozkurt ve diğerleri (2015) tarafından yapılan çalışmada da öğrencilerin büyük bir kısmının müziği eğlenmek ve mutlu olmak için dinledikleri saptanmıştır. Müzik türü tercihinde kardeş etkisinin bulunması, öğrencilerin müzik türü tercihlerinin belirlenmesinde aile ve çevrenin etkisinin bulunduğunu göstermektedir. Yağışan (2013, s. 102) tarafından yapılan çalışmada da öğrencilerin ve ailelerinin müzik türü tercihlerindeki benzerlik, ailede dinlenilen müzik türlerinin bireylerin tercihlerini etkilediğini ortaya koymuştur.

Araştırmada, okul şarkılarının öğrenciler tarafından az tercih edilen bir müzik türü olduğu tespit edilmiştir. Bunun nedeni ise öğrenciler tarafından, bu türün kimse tarafından dinlenmemesi, hiçbir yerde çalmaması, arkadaşlar arasında alaya alınma korkusu, şarkıların çocukça olarak nitelendirilmesi, şarkıların sevilmemesi ve güzel olmaması olarak ifade edilmiştir. Dar bir ses aralığına sahip olan okul şarkıları temel müzik eğitiminin araçları olmalarının yanı sıra kimi zaman bilgi, beceri ve değerlerin aktarımında da işlevsel olarak kullanılabilmektedir. Müziğin etkili mesaj verme özelliği düşünüldüğünde, okul şarkılarının önemi ortaya çıkmaktadır. Ancak okul şarkılarının popüler kültürün ürünü olan popüler müzik türlerine yenildiği de bir gerçektir. Okul şarkılarını öğrenmeleri ve dinlemeleri beklenen ilkokul çocuklarının, bu şarkıları çocukça görmeleri, alay konusu yapmaları, güzel görmemeleri ve sevmemeleri kayda değer bir sonuçtur. Bir katılımcının "Okul şarkıların dinlersem herkes benimle alay eder." sözleri ile bir diğer katılımcının "Okul şarkılarımı kimse dinlemiyor, bu şarkıların modası geçti." sözleri bu müzik türünün dinlenmeme nedenlerini açıça ortaya koymaktadır.

Okul şarkılarının dinlenme oranının azalmasında eğitim sistemimizin de etkili olduğu söylenebilir. Türk Eğitim Sisteminin sınav odaklı bir sistem olması, müzik derslerinin ve müzik eğitiminin dışlanmasına, bu dersin ve müzik eğitiminin hem öğrenci hem de veli gözündeki değerinin azalmasına neden olmaktadır. Ayrıca, okulun farklı kültürlerden gelen bireyleri bütüncül bir anlayışla istendik yönde eğitme görevi ve çabası, daha güçlü olan popüler kültür ve bu kültürü yayan teknoloji ve iletişim araçları karşısında zayıf kalmıştır. Dolayısıyla öğrencilerin müzik gereksinimlerini giderme görevini okullar değil, popüler müzik türlerini pompalayan medya üstlenmiş; cep telefonları, internet ve diğer teknolojik 
araçlar da bunu desteklemiştir. Müzik kanallarında, internet sitelerinde ya da diğer müzik sunan elektronik kaynaklarda/ortamlarda okul şarkılarına neredeyse hiç yer verilmemesi, öğrencilerin bu müzik türünün farkına varmalarını ve bu türü sevmelerini engellemektedir. Bir katılımcının "Okul şarkıları televizyonda çıkmıyor. Bu şarkıların klibi de yok." sözleri bu anlamda dikkate değerdir. Ayrıca, akademik başarı (test ve soru çözme, sınav kazanma) odaklı velilerin, çocuklarının akademik başarısı için müziği ve sanatı öteleme çabalarının da bu sonuçta etkili olduğu söylenebilir. Çocukların eğitim müziklerinin yanında popüler müzik dinleme ve söyleme potansiyellerini geliştirmek, şarkı dağarcıklarını desteklemek ve şarkıları sevdirmek amacıyla yapılan TRT Popüler Çocuk Şarkıları Yarışması'na (Tut \& Kıroğlu, 2017, s. 563) son verilmesi de bu düşüncemizi destekler nitelikte olumsuz bir uygulamadir.

Ayrıca okul şarkılarının tercih edilmemesinde ergenlik ve akran etkisi olduğu da söylenebilir. Katılımcılar tarafından, bu müzik türünü tercih edilmemesinde alaya alınma korkusunun ve bu müziğin başkalarınca (akranlarca) dinlenmiyor olmasının ifade edilmesi bu tespitimizi destekler niteliktedir. Çocukların toplumsal kabul görmek, bir gruba ait olmak, akran güveni ve sevgisi kazanmak gibi bir sorunlarının olduğu bilinmektedir. Çocukların akranları arasında alaya alınmaktan ve dışlanmaktan çekindikleri bir gerçektir. Dolayısıyla akran kabulüne ve iletişime ilişkin kaygıların çocukların tercihlerini de etkilediği söylenebilir. Çünkü toplumsal kabul yoksunluğu ve yakın akran iletişiminin olumsuzluğu korkusu bireyde uysal/itaatkâr olma davranışlarının gelişmesine neden olur (Sübaşı, 2010, s. 55). Ayrıca, okul şarkılarının çocukça bulunması, ergenliğin başlangıç yıllarında olan öğrencilerin bir değerlendirmesi olarak kabul edilebilir. Çünkü alanyazında ergenliğin başlangıc 10 yaş; hatta ırk, iklim ve beslenme şartları gibi değişik faktörlere bağlı olarak 8 yaş olarak ifade edilmektedir (Koç, 2004, s. 233). Ergenliğe girmiş çocukların kendilerini büyümüş olarak algılamaları, büyük gibi davranışlar sergilemeleri, her fırsatta çocuk olmadıklarını ifade etmeleri bilinen özelliklerindendir.

Araştırmada, öğretmenlerin ve velilerin öğrenciler tarafından en çok tercih edilen müzik türlerini (Hiphop-Rap, Pop, Rock) kötü ve faydasız olarak nitelendirdikleri, öğrencilerin ise öğretmen ve velilerin aksine, tercih ettikleri müzik türlerini iyi ve faydalı olarak değerlendirdikleri tespit edilmiştir. Ayrıca araştırmada, öğretmenlerin ve velilerin öğrenciler tarafından en çok tercih edilen müzik türlerini asilik, argo, cinsellik, şiddet, madde bağımlılı̆̆ı ve istismar gibi olumsuz metaforlarla tanımladıkları belirlenmiştir. Müzikal uyaranların, doğru kullanıldığında insanlar üzerinde olumlu, yanlış kullanıldığında ise olumsuz etkiler oluşturma özellikleri bulunmaktadır. Özelikle aykırılığı, isyanı, madde bağımlılığını, şiddeti, cinselliği, küfre varan argoyu işleyen/kullanan popüler müzik türlerinin (Hiphop-Rap, Pop, Rock, Heavy Metal, Techno, Punk) çocuklar üzerinde yıkıcı etki oluşturdukları bilinmektedir (Devlin \& Seidel, 2009; Güner, 1995; Güner, 1998; Hedricks, Robinson, Bradley \& Davis, 1999; Sezer, 2011; Scheel \& Westefeld, 1999; Ögel, Ermağan, Eke \& Taner, 2007). Öğrencilerin en sık dinledikleri Hiphop-Rap müzik türüne ait şarkıların önemli bir kısmının sözleri son derece ağır küfürler, hakaretler, beddualar, argo sözler ile en ileri derecede şiddet ögeleri barındırmaktadır (Ang1, 2013, s. 69; Taşal \& Vural, 2011, s. 257). Bir katılımcının "Son yıllarda bütün medyada çok sık yer alan müzik türlerinin çocukları şiddet eğilimli hale getirdiğini söyleyebilirim. Bu müziklerin sözleri de klipleri de kavga, şiddet, kırma ve dökme yoğunlukludur." sözleri ile bir diğer katılımcının "Öğrencilerin son yıllarda sıkça dinledikleri Hiphop-Rap gibi müzik türlerinin cinsellik içerdiği, bu tür müziklerde argo sözcüklerin ve hatta küfre varan sözlerin çokça yer aldı bir gerçektir." sözleri dikkate değerdir. 
Popüler müziğin her kesim tarafından her zaman kötü olarak algılandığını/değerlendirildiğini iddia etmek gerçekçi olmaz. Halka ait ögeleri fazlasıyla barındıran; evde, arabada, alış veriş alanlarında, sokakta hemen hemen her yerde dinlenen ve bu nedenle de halk tarafından benimsenen ve pratiklerinde yer alan popüler müziğin, müzik sentezinin zemini olması gerektiği yönünde görüşler de bulunmaktadır (Sakar, 2009, s. 388).

Popüler kültürü, kitle ve kitle kültürü bağlamında ele alan görüşler, popüler kültürün ve popüler müziğin halkın büyük çoğunluğu tarafından üretilen ve tüketilen, niteliği düşük kültürler olduğunda israrcıdırlar (Sakar, 2009, s. 386). Popüler müzik türlerinin depresyon, suça yönelme, kendine ve çevresine zarar verme, madde kullanma gibi istenmeyen tutum ve davranışların ortaya çıkmasına neden oldukları, bireyde hüzün ve mutsuzluk hisleri uyandırdıkları bilimsel bir saptamadır (Martin, Clarke \& Pearce, 1993). Bir katılımcının "Hiphop-Rap ve benzeri müzikler genel Türk ahlak anlayışına aykırıdır. Bu müzikler argoyu ve cinselliği kutsamakta, şiddeti vurgulamakta, bağımlllı̆̆ özendirmektedir" sözleri ile bir diğer katılımcının "Popüler müzik türleri hem sanatçısı hem de klipleriyle istismarı özendirmekte, ahlaksızlığı yaygınlaştırmakta, alkol ve madde bağımlılı̆̆ını özendirmektedir." sözleri araştırma sonuçlarını destekler niteliktedir. Popüler müziğin ve alt türlerinin bireylerin en fazla ilişki içerisinde olduğu müzik türleri olmaları; popüler müziğin, hem öğretmenlerin hem de velilerin dikkatlerinin merkezinde yer almasını sağladığı söylenebilir. Bu sonuç, popüler müziğin okul ve akademik başarı odaklı ebeveynler ve öğretmenler tarafından olumsuz algılanmasına ve çocuklar tarafından dinlenmesinin sınırlandırılmasına neden olabilmektedir. Bir katılımcı velinin "Öğrencileri yanlış yollara yönlendiren bu müzikler yasaklanmalıdır bence." sözleri, ebeveynlerin popüler müzik türlerine ilişkin rahatsızlıklarını dile getirmektedir. Akademik başarıya ve sosyal statüye sahip olma arzusunda olan ailelerde ve öğretmenlerde çocuklarını toplumda genel kabul gören ve statü göstergesi olan müziklere ve müzik eğitimine yönlendirme çabası olduğu da söylenebilir.

\section{SONUÇ}

Araştırma sonuçları bir bütün olarak değerlendirildiğinde, çocukların popüler müzik türlerini daha çok tercih ettikleri, bu müzik türlerini tercih etmelerinde görsel ve işitsel medyanın ve bilgisayar teknolojisindeki gelişmelerin büyük etkisinin olduğu anlaşılmaktadır. Araştırmada, okul şarkılarının öğrenciler tarafından dinlenme oranının son derece düşük olduğu, bu düşüklüğün en önemli nedenlerinin ise, bu müzik türüne medya araçlarında sıkça yer verilmemesi ve bu türün çocukça bir müzik türü olarak algılanması olduğu anlaşılmaktadır. Öğretmenlerin ve ebeveynlerin çocuklar tarafından tercih edilen popüler müzik türlerini faydasız ve kötü olarak tanımlamaları/değerlendirmeleri de araştırmada ulaşılan bir diğer sonuçtur.

Popüler müzik kültüründe hedef kitlenin/dinleyicinin, kendisine ne verilirse hemen alan bir kitle olmaktan çok, kendi estetik beğenisi yönünde davranarak ürün tüketen bir kitle olduğu gerçeği de göz ardı edilmemelidir. Popüler müziğin parasal kazanç sağlama kaygılarıyla üretildiği, işitsel ve görsel içeriklerinde çocuklara zararlı olabilecek ögelerin bulunduğu bilinmektedir. Ancak popüler müzik türlerinin özgürleştirici ve demokratikleştirici özelliklerinin bulunduğu ve toplumların bazı sosyo-kültürel gerçekliklerine dikkat çektiği de bir gerçektir. Bu açıdan bakıldığında, popüler müzik türleriyle çocukların duyarlılıklarının, farkındalıklarının ve yaratıcılıklarının 
geliştirilebileceği söylenebilir. Çocukların, hayranı oldukları popüler müzik yıldızlarının şarkıları üzerine kendilerinin söz yazmaya teşvik edilmeleri bile onların potansiyel üretici ve yaratıcı bireyler olmalarını sağlayabilir.

Çocukların müzik tercihlerinde bazen bilinçsiz davranabildikleri söylenebilir. Bu durumda, eğitimcilerin ve ailelerin çocukların müzik tercihleri noktasında işbirliği içinde olmaları ve çocukları zararlı ögeler içeren müzik türlerinden uzak tutmaları önemlidir. Bir çocuğun Rock, Rap veya Heavy metal dinliyor olmasının, onun mutlaka isyankâr olmasını veya o alt kültüre özgü kalıpları benimseyip ona göre giyinmesini ve davranmasını gerektirmediği bilinciyle hareket edilerek; alınacak önlemlerin panik ve üst düzeyde kaygılardan uzak, baskı ve şiddet içermeyen bir tarzda olmasına özen gösterilmesi gerekir.

Öğrencilerin müziği bütün boyutlarıyla deneyimleyebilmeleri için fırsat yaratılmalı ve ortam sağlanmall; öğrenciler müziğin içerisine çekilip, onların zihinsel, duygusal, entelektüel ve sanatsal kapasiteleri artırılmalıdır. Okullarda gerek ders içi gerek ders dışı eğitim çalışmalarında öğrencilerin bireysel gelişimlerini destekleyici müzik etkinliklerine daha sık yer verilmeli; istekli ve yatkın olan öğrenciler öncelikli olarak müzik eğitimine yönlendirilmeli ve bu öğrenciler öğretmenler, okul yönetimi ve veliler tarafından desteklenmelidir.

Öğrencilerin müziksel ilgilerine yanıt verirken, onların müziğin teorisini ve kültürünü kavrayabilmelerini, nitelikli birer müzik dinleyicisi ve tüketicisi olabilmelerini sağlayıcı çalışmalara da ağırlık verilmelidir. Popüler müziğe aktif ya da pasif olarak yoğun ilginin varlı̆̆ı, popüler müziğin küçük yaş grupları içerisinde bile sınırları zorlayıcı bir tercih nedenine dönüşmüş olması, müzik eğitimcilerinin popüler müziği müzik öğretiminde önemli bir kaynak olarak kullanmalarını gerektirir. Öğrencilerin müziğe yönelik bilgi ve tercihlerinin kaynağının kontrolsüz medya ve teknolojik araçlar değil, okulun müzik dersleri olması sağlanmalı ve bu amaçla müzik dersleri öğrencilerin ilgileri çerçevesinde yeniden gözden geçirilmelidir. Ayrıca, okul şarkıları çağdaş müzik formları ışığında yeniden ele alınarak, öğrencilerin ilgi duyacağı ve seveceği şekilde düzenlenmelidir.

Birçok açıdan öğrencilerin yaşamları üzerinde önemli etkileri olan öğretmenlerin popüler kültür ve popüler müzik hakkında da geniş bir bilgi birikimine sahip örnek dinleyiciler olmaları sağlanmalıdır. Öğretmenlerin, kültürel sermayelerini doğru politika ve düşünceler ışı̆̆ında geliştirmelerinin kendilerine birçok alanda başarı getireceği bilinmektedir. Bundan dolayı, müzik öğretmenleri sadece nota okuyabilen ve şarkı öğretebilen öğretmen stereotipinden, entelektüel bilgi birikimine sahip ve bilgisine başvurulabilecek müzik pratisyenlerine dönüşmelidirler.

Aynı anda tınlayan seslerin, belli bir amaca yönelik olarak ve zamanla değişen görüşlere göre bir düzen içinde kaynaşmasıdır çokseslilik. Klasik müziğin özünü oluşturan çoksesliliğin entelektüel gelişmeye, çok boyutlu düşünmeye önemli katkılar sunduğu açıktır. Dolayısıyla çocuklarda farklılıkları kabullenme, farklı olana anlayış gösterme, olay ve olgulara farklı açılardan bakma kültürü oluşturmada klasik müziğin önemli etkileri olduğu söylenebilir. Diğer müzik türlerine göre klasik müzik dinlemenin, bir olgunluk ve entelektüel düzey gerektirdiği bir gerçek olmakla birlikte, derslerde bu türün güzel örneklerinin sergilenmesi, teneffüslerde ve diğer dinlenme saatlerinde bu türün öğrencilere dinletilmesi bu müziğe olan ilgiyi ve sevgiyi artıracaktır. 
Olumsuz duyguları barındıran, bağımlılığı özendiren, cinselliği ve asiliği ön plana çıkaran, amaçsız bir yaşamı teşvik eden ve şiddet içeren mesajlar yayan müzik türlerinin, çocukların yoğun zaman geçirdikleri yerlerde çalınmasına/dinletilmesine sınırlamalar getirilmeli ve bu müzik türleri yerine eğitici, eğlendirici ve mutluluk sağlayıcı müzik türleri tercih edilmelidir. Müziğin insanın yapıp-etmelerini kapsayan kültürün en önemli unsurlarından biri olması, onun evrensel olduğu kadar ulusal olma özelliğinin de ön plana çıkmasını sağlar. Her yönüyle kendine özgü müziği olmayan toplumların uluslaşma sürecini tamamladıklarını söylemek güç olacaktır. Bundan dolayı, kültürel zenginliğimizi barındıran Türk Sanat Müziği ve Türk Halk Müziği türleri ön plana çıarılmalı, milli kültürün vazgeçilmez bir öğesi olan Türk Müziği baskıdan ve zorlamadan uzak, bilimsel yöntem ve tekniklerin kullanıldığı planlı, amaçlı ve istikrarlı etkinlikler yoluyla öğrencilere sevdirilmelidir.

$\mathrm{Bu}$ araştırma, ilkokul dördüncü sınıf öğrencileri ve sinıf öğretmenleriyle sınırlandırılmıştır. Bu araştırmanın, farklı yaş gruplarına ve farklı eğitim düzeylerine sahip öğrencilerin ve farklı branşlardan öğretmenlerin örneklem alınarak yapılması da alana katkı sağlayacaktır.

\section{SUMMARY}

Social and cultural changes that have occurred in Turkey, the country's understanding of art affect the music closely culture. As a result of the cultural and artistic change that occurred in the society, there was a change in the understanding of music. Due to this fact, the relations between those who produce music and who listen to music have also changed. This change has affected individuals' music habits and preferences in many ways. In particular, the fact that music has become a commercial element has led the music market to target individuals' musical pleasures, musical habits and trends.

Students' pleasures and perceptions towards music can be influenced by the school environment, music lessons, teachers' attitudes and behaviors towards music, the personality of music-related people and teachers, their books, music activities carried out inside or outside the school, written, visual and audio media. One of the reasons for this study is the idea that determining the children's knowledge, attitudes and behavior towards music will be useful in directing music education as well as providing important information and perspectives for decision making mechanisms about music education.

This study aims to determine primary school fourth grade students' preferences for the genre of music, the reasons for these preferences and the opinions of the type of music they prefer. Also, it aims to reveal how parents and teachers view students' preferences of music genre, their views on the benefit of the preferred genre and how they define the most preferred genre.

In this study, phenomenological design, one of the qualitative research designs, was used. The study group of the research consists of 27 fourth grade students, 12 primary school teachers and 27 parents of students. The study was carried out in 3 primary schools. Schools were grouped according to the administrative structure of the settlement where the school is located (province, district, village). Participating teachers, parents and students were determined by criterion sampling method, one of the purposeful sampling methods. Research data were collected using a semi-structured questionnaire and semi-structured interview form. Data collection tools were developed by the researcher. In the study, the 
ethical principles stated in the Higher Education Institutions Scientific Research and Publication Ethics Directive were meticulously followed. In the research, the data obtained by semi-structured questionnaire were analyzed by descriptive analysis method and the qualitative data obtained through interviews were analyzed using content analysis method.

In the research, Hiphop-Rap music type is the most preferred music type by students. This type is followed by Turkish Pop, Foreign Pop and Rock genre, and Turkish Folk Music, Arabesque-fantasy, Turkish Art Music, Original Music and Sufi Music are the least preferred music types by all students. Classical Music is a less preferred music genre and it is understood that school songs are a type of music least preferred by all students, especially male students.

In the research, it was found that listening to the genre of music was the first degree of influence in the preference of the students. Loving, having fun, being listened to by other family members, being found funny, being beautiful, and appealing to emotions are other reasons for choosing the music genre. The fact that the music genre is listened by everyone constitutes the reason for being preferred by children.

In the research, it was found that teachers and parents describe the music types (Hiphop-Rap, Pop, Rock) which are preferred most by the students as bad and useless while students, unlike teachers and parents, evaluate the music types they prefer as good and useful. In addition, it was determined in the research that teachers and parents define the most preferred music types by students with negative metaphors such as rebelliousness, slang, sexuality, violence, substance abuse and abuse. It is a scientific finding that popular music genres cause unwanted attitudes and behaviors such as depression, crime, harm to themselves and their surroundings, using substance, and create feelings of sadness and unhappiness in the individual.

An opportunity should be created and an environment should be provided for students to experience music in all its dimensions. Music activities that support students' personal development should be included more frequently in schools, both in and out of class. willing and inclined students should be directed primarily to music education and these students should be supported by teachers, school management and parents.

The source of students' knowledge and preferences towards music should be the music lessons of the school, not uncontrolled media and technological tools. For this purpose, music lessons should be revised within the framework of students' interests; teachers, on the other hand, should be ensured to be exemplary listeners with a wide knowledge of popular culture and popular music.

Restrictions should be placed on listening to music types that have negative emotions, encourage addiction, highlight sexuality and rebelliousness, promote an aimless life and give violent messages in places where children spend time intensely. Music genres with educational, entertaining and relaxing features should be preferred instead. 
Makale Bilgileri

Etik Kurul Kararı:

Araştırmanın Etik Kurulu Raporu vardır. (Onay: 22.07.2020, 2020/ 6-3)

Katılıme Rızası: Araştırmaya katılanlara çalışmanın amacı ifade edilerek rızaları alınmıştır.

Mali Destek: Çalışma için herhangi bir kurum ve projeden mali destek alınmamıştır.

Çıkar Çatışması: Çalışmada kişiler ve kurumlar arası çıkar çatışması bulunmamaktadır.

Telif Hakları:

Telif hakkına sebep olacak bir materyal kullanılmamıştır.

Article Information

Ethics Committee Approval: The research has Ethics Committee Report (Approval:22.07.2020,2020/6-3)

Informed Consent:

The purpose of the study is explained to the particants and their informed consent was obtained.

Financial Support: The study received no financial support from any institution or project.

Conflict of Interest: The authors declare that declare no conflict of interest.

Copyrights:

No material subject to copyright is included. 


\section{KAYNAKÇA}

Akkol, M. L. (2015). Toplumsal statü farkl1liklarının ve eşitsizliklerin müzikal anlam farklılıklarının oluşumuna etkileri. Ö. Özaltunoğlu (Ed.), II. Uluslararası Güzel Sanatlar Bilimsel Araştırma Günleri Bildirileri içinde (s. 311-324), Cumhuriyet Üniversitesi, Sivas.

Akkol, M. L. (2018). Müzik sosyolojisinde T. W. Adorno'nun yeri. Alternatif Politika, 10(1), 111-130.

Akkol, M. L. (2019). Kitle kültürü ve kültür endüstrisi kavramlarının Frankfurt Okulu Düşüncesi üzerinden analizi. Uluslararası İnsan Çalı̧̧maları Dergisi, 2(3), 49-64.

Aksu, C. (2008). Türk müzik devrimine güncel bakış sonuçtan-sürece, süreçten-günümüze yeni çıkarımlar. Atatürk Ünversitesi Güzel Sanatlar Fakültesi Dergisi, (13), 17-26.

Algül, A. (2019). Popüler kültür ve popüler edebiyat. European Journal of Educational and Social Sciences, 4(2), 142-153

Angı, Ç. E. (2013). Müzik kavramı ve Türkiye'de dinlenen bazı müzik türleri. İdil, 2(10), 5981. doi: 10.7816/idil-02-10-05

Artemiz, B. (2009). Ergenlerin farklı müzik türlerine ilişkin ilgileri ile kişilik özellikleri arasındaki ilişkinin incelenmesi (Yayımlanmamış yüksek lisans tezi). Maltepe Üniversitesi, İstanbul.

Aydıner-Uygun, M. (2015). Öğretmen adaylarının geleneksel müzik türlerine ilişkin algılarının metaforlar aracılığıyla incelenmesi. AKÜ AMADER, (1), 1-16. Doi: 10.5578/AMRJ.8905.

Aydoğan, Y. \& Gürsoy, F. (2007). Müzik dinleme alışkanlıklarının ve bazı değişkenlerin lise ikinci sınıf öğrencilerinin sürekli kaygı düzeyleri üzerindeki etkilerinin incelenmesi. Abant İzzet Baysal Üniversitesi Ĕ̆itim Fakültesi Dergisi, 7(1), 59-67

Bedir, G. \& Akkurt, A. (2012). Şarkılarla coğrafya öğretimi, Doğu Coğrafya Dergisi, 17(28), 303-316.

Bozkurt, S. S., Zahal, O. \& Türe Uyan, D. (2015). Ortaokul öğrencilerinin duygu durumlarına göre dinledikleri müzik türlerinin incelenmesi. International Journal of Social Sciences (JASSS), (39), 541-567.

Büyüköztürk, Ş., Akgün, Ö. E., Karadeniz, Ş., Demirel, F. \& Çakmak, E. K. (2018). Bilimsel araştırma yöntemleri. Ankara: Pegem Akademi Yayıncılık.

Çakmak, H. (2018). Türkiye'de hiphop kültürü ve rap müzik. Sosyal Demokrat Dergi, 95(96), 18-21.

Çetinkaya, Y. (1999). Müzik yazıları.İstanbul: Kaknüs Yayınları

Çiftçi, E. (2010). Popüler kültür, popüler müzik ve müzik eğitimi. Erzincan Eğitim Fakültesi Dergisi, 12(2), 149-161.

Demir, Ö. (2020, 03 Temmuz). Sosyal bilimler sözlüğü. Erişim adresi: http://omerdemir.net/sosyal-bilimler-sozlugu/

Devlin, J. M. \& Seidel, S. (2009). Music preferences and their relationship to behaviors, beliefs and attitudes toward aggression. Reports - Research (Online submission to Eric.ed.gov). 131.

Düzbastılar, M. (2017). Müzik eğitiminin müzikal tercihler üzerine etkisi. International Journal of Social Sciences and Education Research, 3(5), 1485-1493.

Erdal, B (2009). Müzik tercihi ve kişilik ilişkisi. C.Ü. Sosyal Bilimler Dergisi, 35(2), 188-196. 
Erdal, B. \& Ok, Ü. (2012). Müzik tercihinde inanç biçimlerinin rolü. International Journal of Social Science, 5(3), 59-74,

Erdem, C. (2011). Ergenin müzik ile iletişimi. Türk Pediatri Araştırmaları Dergisi, 46(Özel sayı), 19-21. doi: 10.4274/tpa.46.25

Erdoğan, İ. \& Alemdar, K. (2005). Popüler kültürr ve iletişim. İstanbul: Erk Yayınları.

Gidiş, V. (2018). Popüler kültür ve müzik ilişkisi bağlamında popüler Türk sanat müziği şarkılarında kullanılan makamlara ilişkin bir değerlendirme. Türk \& İslam Dünyası Sosyal Araştırmalar Dergisi, 5(18), 331-350

Güner, N. (1995). Ergenlerin dinledikleri müzik türünün depresyon ve saldırganlık düzeyine etkisi (Yayımlanmamış yüksek lisans tezi). Hacettepe Üniversitesi, Ankara.

Güner, N. (1998). Ergenlerin dinledikleri müzik türü ile saldırganlık düzeyleri arasındaki ilişkinin incelenmesi. VII. Ulusal Ĕ̆itim Bilimleri Kongresi kitabı içinde (cilt 1, s. 291-299), Ankara: Pegem Akademi.

Hedricks, C. B., Robinson, B., Bradley, L. J. \& Davis, K. (1999). Using music technigues to treat adolescent depression. Journal of Humanistic Counseling, Education Development, (38), 39-46.

Kaplan, A. (2005). Kültürel müzikoloji. İstanbul: Bağlam Yayıncılık.

Kaya, K., Baysal, H. \& Kurt, E. V. (2007). Popüler kültür bağlamında müzik yarışması ve magazin programlarının üniversite gençliği üzerindeki etkileri (SDÜ örneği). Süleyman Demirel Üniversitesi İktisadi ve İdari Bilimler Dergisi, 12(3), 35-52.

Kılıç, I. (2016). Ortaokul öğrencilerinin müzik ile ilgili görüşlerinin incelenmesi. Eğitim ve Öğretim Araştırmaları Dergisi, 5(3), 360-371.

Koç, M . (2004). Gelişim psikolojisi açısından ergenlik dönemi ve genel özellikleri. Erciyes Üniversitesi Sosyal Bilimler Enstitüsü Dergisi, 1(17), 231-238.

Kongar, E. (2014). Toplumsal değişme kuramları ve Türkiye gerçeği. İstanbul: Remzi Kitabevi.

Madsen, C. K. \& Kelly, S. N. (2002). First remembrances of wanting to become a music teacher. Journal of Research in Music Education, 50(4), 323-332. doi: 10.2307/3345358

Martin, G. Clarke, M. \& Pearce, C. (1993). Adolescent suicide: Music preference as an indicator of vulnerability. Journal of the merican Academy of Child $\mathcal{E}$ Adolescent Psychiatry 32(3), 530-535.

Mills, J. (1996). Starting at secondary school. British Journal of Music Education, 13(1), 5-14. doi: $10.1017 / S 0265051700002904$

Ok, A. (2004). 12 Eylül şiddeti ve arabesk. İstanbul: Akyüz Yayıncılık.

Oktay, A. (2002). Türkiye'de popüler kültür. İstanbul: Everest Yayınları.

Ögel, K., Ermağan E., Eke, C. Y. \& Taner, S. (2007). Madde deneyen ve denemeyen ergenlerde sosyal aktivitelere katılım: İstanbul örneklemi. Journal of Dependence, 8(1), 1823.

Ögel, K., Sarp, N., Gürol, D. T. \& Ermağan, E. (2014). Bağımlı olan ve olmayan bireylerde farkındalık (mindfulness) ve farkındalığı etkileyen etkenlerin incelenmesi. Anadolu Psikiyatri Dergisi, (15), 282-288.

Özbek, M. (2013). Popüler kültür ve Orhan Gencebay arabeski. İstanbul: İletişim Yayınları.

Özkan, H. H. (2006). Popüler kültür ve eğitim. Kastamonu Eğitim Dergisi, 14(1), 29-38.

SEFAD, 2020; (44): 355-378 
Öztürk, O. M. (2002). Türkiye'de yaşanan modernleşme süreci ve Anadolu yerel müzikleri. 21. YY Başında Türkiye'de Müzik Sempozyumu Bildirisi, Ankara: SCA Müzik Vakfı,

Sakar, M. H. \& Maba, A. (2015). Ortaokul öğrencilerinin müziksel tercihleri ve dinleme pratikleri. Uluslararası Sosyal Araştırmalar Dergisi, 8(36), 980-996

Sakar, M. H. (2009). Popüler müzik ve müzik eğitimi. Uluslararası Sosyal Araştırmalar Dergisi, 2(8), 385-393

Scheel, K. R. \& Westefeld, J.S. (1999). Heavy metal music and adolescent suicidality: An emprical investigation. Adolescence, 34(134), 253-273.

Schwartz, K. D K. \& Fouts, T. G. (2003). Music preferences, personality style and developmental issues of adolescents. Journal of Youth and Adolescence, 32(3), 205-213.

Sezer, F. (2011). Öfke ve psikolojik belirtiler üzerine müziğin etkisi. Uluslararası İnsan Bilimleri Dergisi, 8(1), 1472-1493.

Sübaşı, G. (2010). Ergenlerde sosyal kaygı ve akran ilişkilerinin psikobiyolojik sosyal kaygı modeline göre sinanması. Yüzüncü Yıl Üniversitesi Eğitim Fakültesi Dergisi, VII(II), 52-68

Şahin, M. \& Duman, R. (2008). Cumhuriyetin yapılanma sürecinde müzik eğitimi. Çağdaş Türkiye Tarihi Araştırmaları Dergisi, 7(16-17), 259-272.

Taşal, B. \& Vural, F. (2011). Şarkı sözlerinde şiddet öğesi: Aksaray ili ilköğretim ikinci kademe öğrencileriyle yapılan bir çalışma. Selçuk Üniversitesi Sosyal Bilimler Enstitüsü Dergisi, (25), 251-259

The American Academy of Pediatrics. (2009). Policy statement-Impact of music lyrics and music videos on children and youth. AAP News \& Journals, 124(5), 1488-1494. doi: 10.1542/peds.2009-2145.

Tut, E. \& Kıroğlu, K. (2017). TRT'nin popüler çocuk şarkıları yarışması'nda finale kalan eserlerin değerler eğitimi açısından incelenmesi. Uluslararası Sosyal Araştırmalar Dergisi, 10(48), 561-569

Uçan, A. (2018). Müzik eğitimi, temel kavramlar, ilkeler ve yaklaşımlar. Ankara: Arkadaş yayınları.

Uluçay, T. (2018). Lise öğrencilerinin dinledikleri müzik türlerinin şiddet eğilimlerine etkisi. Atatürk Üniversitesi Güzel Sanatlar Enstitüsü Dergisi, (41), 135-153, doi: 10.32547/ataunigsed.450424

Ulutürk, N. (2008). Anadolu güzel sanatlar lisesi müzik bölümü öğrencilerinin dinlemeyi tercih ettikleri müzik türleri (Yayımlanmamış yüksek lisans tezi). Abant İzzet Baysal Üniversitesi, Bolu.

Yağışan, N. (2013). Üniversite öğrencilerinin müzik tercihleri ve saldırganlıkla ilişkisi. Sanat Eğitimi Dergisi, 1(2), 96-113, doi:10.7816/sed-01-02-07

Yıldırım, A. \& Şimşek, H. (2018). Sosyal bilimlerde nitel araştırma yöntemleri. Ankara: Seçkin Yayınları. 